The Breeder's Exemption under the 1991 International Convention for the Protection of New Plant Varieties and the Convention on Biological Diversity and its Nagoya Protocol

Dr Charles Lawson

Australian Centre for Intellectual Property in Agriculture

Griffith Law School

Griffith University

Gold Coast Queensland 4222

$\mathrm{T}-(07) 55527249$

F - (07) 55528667

E-c.lawson@griffith.edu.au 
The Breeder's Exemption under the 1991 International Convention for the Protection of New Plant Varieties and the Convention on Biological Diversity and its Nagoya Protocol

\section{The author}

- Charles Lawson is a professor at the Australian Centre for Intellectual Property in Agriculture at Griffith University, Australia.

\section{This article}

- The 1991 International Convention for the Protection of New Plant Varieties (UPOV 1991) provides for a breeder's exemption allowing the protected plant variety to be used to breed new varieties.

- The United Nations Convention on Biological Diversity (CBD) and its Nagoya Protocol provide a scheme for access plant materials (genetic resources) that might be used for breeding new varieties and details an obligation to share any benefits.

- This article shows that while the CBD and Nagoya Protocol and UPOV 1991 operate separately, in their implementation in domestic laws the CBD/Nagoya Protocol access and benefit-sharing contracts can limit the UPOV 1991's breeder's exemption, restricting further breeding of new varieties. 


\section{The Breeder's Exemption under the 1991 International Convention for the Protection of New Plant Varieties and the Convention on Biological Diversity and its Nagoya Protocol}

\section{Introduction}

The raw materials for plant breeding are parental varieties that can be manipulated in various ways to result in progeny that can be selected for desired characters. As a consequence the progeny plants improve the stock of plant materials available and encourage and enable yet more breeding of other desirable characters. Breeding plants has attracted intellectual property schemes intended to promote further plant breeding by allowing breeder's to control various uses of their bred plants and their components and products. ${ }^{1}$ The most significant of these schemes is set out in the International Convention for the Protection of New Plant Varieties (UPOV) that provides for a plant breeder's right. ${ }^{2}$ This right is a series of exclusive rights to deal with the progeny of plant breeding being production or reproduction, conditioning for the purpose of propagation, offering for sale, selling or other marketing, exporting, importing, and stocking for any of the purposes, of propagating materials, harvested materials and essentially derived varieties. ${ }^{3}$ These rights, however, are limited by the so-called 'breeder's exemption' - an exemption that allows the breeding of a new variety using parental varieties that are protected by a plant breeder's right. ${ }^{4}$

In recent times a series of other developments have affected the ways raw materials for breeding may be dealt with. The United Nations' Convention on Biological Diversity (CBD) ${ }^{5}$ provides for a scheme for access and benefit-sharing from using 'genetic resources' (that includes plants) from 29 December $1993 .{ }^{6}$ More recently the Nagoya Protocol on Access to Genetic Resources and the Fair and Equitable Sharing of Benefits Arising from their Utilization to the Convention on Biological Diversity (Nagoya Protocol), ${ }^{7}$ a protocol to the

\footnotetext{
${ }^{1}$ See International Union for the Protection of New Varieties of Plants, What It Is, What It Does, UPOV Publication No 437(e) (UPOV, 2011) p 1.

${ }^{2}$ International Convention for the Protection of New Plant Varieties (1991) 815 UNTS 89, being the original agreement of 2 December 1961 and revised on 10 November 1972, 23 October 1978 and 19 March 1991 (UPOV 1991).

${ }^{3}$ UPOV, Art 14.

${ }^{4}$ UPOV 1991, Art 15(1)(iii).

${ }^{5}$ Convention on Biological Diversity (1992) 1760 UNTS 79 (CBD).

${ }^{6} \mathrm{CBD}$, Art 15.

${ }^{7}$ Conference of the Parties to the Convention on Biological Diversity, Report of the Sixth Meeting of the Conference of the Parties to the Convention on Biological Diversity (2010) UNEP/CBD/COP/10/27, [103] and Annex (Decision X/1, Annex, pp 89-109) (Nagoya Protocol on Access to Genetic Resources and the Fair and Equitable Sharing of Benefits Arising from their Utilization to the Convention on Biological Diversity) (Nagoya Protocol).
} 
$\mathrm{CBD},{ }^{8}$ provides more detailed obligations for access and sharing benefits from using 'genetic resources' and the traditional knowledge associated with those genetic resources from 12 October 2014. ${ }^{9}$ This article addresses the problems posed by the interaction of the UPOV scheme providing plant breeder's rights with a breeder's exemption for plant breeding using protected plants, and the CBD/Nagoya Protocol providing obligations on those accessing genetic resources and traditional knowledge associated with those resources. The problem arises because the UPOV breeder's exemption allows anyone to use the protected plants to breed new plants while the CBD/Nagoya Protocol potentially limits the likely uses of plants in breeding including plants subject to plant breeder's rights and their progeny. The question is whether the UPOV breeder's exemption takes precedence and so allows accessed plants to be used for breeding without restrictions? The question in the alternative is whether the CBD/Nagoya Protocol enables the UPOV breeder's exemption to be avoided?

The article is structured as follows: the next parts overview the relevant parts of the UPOV breeder's exemption and CBD/Nagoya Protocol access and benefit-sharing scheme; this is followed by an interpretive analysis of the relationship between the CBD and Nagoya Protocol, and the UPOV and the CBD/Nagoya Protocol; then there is an analysis of the operational effects of these international agreements in a domestic law setting framing the analysis in the context of providers of genetic resources and users of genetic resources. The article concludes that even though UPOV and the CBD/Nagoya Protocol are compatible, so that the CBD/Nagoya Protocol does not limit the operation of UPOV, in their operation through domestic laws the contracts contemplated under the CBD/Nagoya Protocol allow the UPOV breeder's exemption to be avoided. In short, CBD/Nagoya Protocol scheme can limit the UPOV breeder's exemption to prevent further plant breeding.

\section{UPOV 1991's breeder's exemption}

The World Trade Organisation's (WTO) Agreement on Trade-Related Aspects of Intellectual Property Rights (TRIPS) sets out the minimum requirements for intellectual property among WTO Members. ${ }^{10}$ TRIPS provides that Members may exclude 'plants ... and essentially biological processes for the production of plants’ from patenting. ${ }^{11}$ This exclusion, however,

\footnotetext{
${ }^{8}$ See CBD, Art 28.

${ }^{9}$ Nagoya Protocol, Arts 6, 7 and 12.

${ }^{10}$ Agreement Establishing the World Trade Organization (1994) 1867 UNTS 154, Art II(2) and Annex 1C (1869 UNTS 299; Trade-Related Aspects of Intellectual Property Rights) (TRIPS).

${ }^{11}$ TRIPS, Art 27(3)(b).
} 
is tempered by the obligation that 'Members shall provide for the protection of plant varieties either by patents or by an effective sui generis system or by any combination thereof'. ${ }^{12}$ Most Members provide an 'effective sui generis system' with the sui generis system predominantly being UPOV. ${ }^{13}$ This makes the UPOV scheme an important global standard for plant intellectual property.

The UPOV scheme was introduced in 1961 and was revised in 1972, 1978 and $1991 .{ }^{14}$ Each of the UPOV 1961/1972, 1978 and 1991 provide for a plant breeder's right that is limited so as to allow a third part to access the variety and use it to breed another variety - the so-called 'breeder's exemption'. ${ }^{15}$ There are presently 52 Members of the 1991 Act, 19 Members of the 1978 Act and 1 Member of the 1961/1972 Act. ${ }^{16}$ The UPOV 1991 is used to illustrate the concern in the following analyses.

UPOV 1991 provides that a plant variety can be registered where it satisfies the threshold requirements of being '(i) new; (ii) distinct; (iii) uniform; and (iv) stable'. ${ }^{17}$ The plant breeder's right ${ }^{18}$ then protects the following exclusive rights: 'in respect of the propagating material of the protected variety shall require the authorization of the breeder: (i) production or reproduction (multiplication), (ii) conditioning for the purpose of propagation, (iii) offering for sale, (iv) selling or other marketing, (v) exporting, (vi) importing, (vii) stocking for any of the purposes mentioned in (i) to (vi)'. ${ }^{19}$ These exclusive rights also extend to 'harvested materials', 20 'products made directly from harvested material', 21 and 'essentially

\footnotetext{
12 TRIPS, Art 27(3)(b).

${ }^{13}$ See Council for Trade-Related Aspects of Intellectual Property Rights, Review of the Provisions of Article 27.3(b): Illustrative List of Questions (2003) IP/C/W/273/Rev.1, pp 9-12. See also Justin Malbon, Charles Lawson and Mark Davison, The WTO Agreement on Trade-Related Aspects of Intellectual Property Rights: A Commentary (Edward Elgar, 2014) p 444.

${ }^{14}$ Rolf Jördens, 'Progress of plant variety protection based on the International Convention for the Protection of New Varieties of Plants (UPOV Convention)' (2005) 27(3) World Patent Information 232-243; Andre Heitz, 'The History of the UPOV Convention and the Rationale for Plant Breeders' Rights' in 1991 Seminar on the Nature and Rationale for the Protection of Plant Varieties Under the UPOV Convention (UPOV, 1994) pp 2526.

${ }^{15}$ UPOV 1961/1972, Art 5(1); UPOV 1978, Art 5(1); UPOV 1991, Art 15(1)(iii).

${ }^{16}$ See International Union for the Protection of New Varieties of Plants, Members of the International Union for the Protection of New Varieties of Plants. [Online]. Available at:

http://www.upov.int/export/sites/upov/members/en/pdf/pub423.pdf (viewed: 9 December 2014).

${ }^{17}$ UPOV 1991, Art 5(1).

${ }^{18}$ UPOV 1991, Art 2.

${ }^{19}$ UPOV 1991, Art 14(1)(a).

${ }^{20}$ UPOV 1991, Art 14(2).

${ }^{21}$ UPOV 1991, Art 14(3).
} 
derived varieties'. ${ }^{22}$ The exclusive rights do not, however, extend to 'acts done for the purpose of breeding other varieties' - the 'breeder's exemption'. ${ }^{23}$

The purpose of the 'breeder's exemption' was clearly that 'there are no restrictions on the use of protected varieties for the purpose of breeding new plant varieties' ${ }^{24}$ In a hypothetical circumstance where a breeder breeds a new variety $\mathrm{C}$ using a protected variety A crossed with a non-protected variety $\mathrm{B}(\mathrm{A} \times \mathrm{B}=\mathrm{C})$, the use of variety $\mathrm{C}$ does not require the authorization of the plant breeder's right holder of variety A (or variety B), except for the limited circumstances where variety $\mathrm{C}$ is an essentially derived variety. ${ }^{25}$ In short, anyone can use a protected variety, including an essentially derived variety to breed a new variety, and there are no limits that can be placed on the breeder by the plant breeder's right holder to limit this breeding. The question now is how does this exemption interact with the CBD and Nagoya Protocol?

\section{The CBD and Nagoya Protocol scheme}

The CBD's objectives are the conservation of biological diversity, the sustainable use of the components of biological diversity and the fair and equitable sharing of the benefits from using genetic resources. ${ }^{26}$ The terms 'biological resources' includes 'genetic resources, organisms or parts thereof', 'genetic resources' means 'genetic material of actual or potential value' and 'genetic material' means 'any material of plant, animal, microbial or other origin containing functional units of heredity'. ${ }^{27}$ There seems little doubt that plants are within the scope of the CBD. ${ }^{28}$

The CBD then recognizes the sovereign rights of Members over their natural resources (including genetic resources) ${ }^{29}$ and requires Members to implement an access and benefitsharing scheme for genetic resources for which they are countries of origin of such resources

\footnotetext{
${ }^{22}$ UPOV 1991, Art 14(5).

${ }^{23}$ UPOV 1991, Art 15(1)(iii).

${ }^{24}$ International Union for the Protection of New Varieties of Plants, Explanatory Notes on Exceptions to the Breeder's Right Under the 1991 Act of the UPOV Convention (2009) UPOV/EXN/EXC/1, [9].

${ }^{25}$ See UPOV/EXN/EXC/1, above n 24, [11]. See Charles Lawson, 'Plant breeder's rights and essentially derived varieties: Still searching for workable solutions’ (2014) 32(8) European Intellectual Property Review 499-517.

${ }^{26} \mathrm{CBD}$, Art 1.

${ }^{27} \mathrm{CBD}$, Art 2.

${ }^{28}$ See Conference of the Parties to the Convention on Biological Diversity, Access to Genetic Resources and Benefit Sharing: Legislation, Administrative and Policy Information (1995) UNEP/CBD/COP/2/13, [49]-[65].

${ }^{29}$ CBD, Art 15(1).
} 
and for genetic resources that Members have acquired in accordance with the CBD. ${ }^{30}$ The scheme requires prior informed consent to access the materials ${ }^{31}$ and mutually agreed terms about access and benefit sharing. ${ }^{32}$ Following the CBD many Members implemented schemes essentially around the conception of a contractual agreement between the provider of the genetic resources and the receiver of those resources (bioprospector) with the contract setting out the prior informed consent, mutually agreed terms and content of the benefits to be shared. ${ }^{33}$ These contracts mostly followed the voluntary guidelines agreed in Bonn Guidelines on Access to Genetic Resources and Fair and Equitable Sharing of the Benefits Arising out of their Utilization (Bonn Guidelines). ${ }^{34}$ At that time these guidelines were considered by some Members to be the basis for developing a binding international instrument. ${ }^{35}$ This also coincided with other Members' concerns expressed at the UN World Summit on Sustainable Development ${ }^{36}$ and at the UN General Assembly ${ }^{37}$ to promote and safeguard the fair and equitable sharing from using genetic resources. ${ }^{38}$ This led to an agreed mandate in the CBD forum to 'elaborate and negotiate' an international instrument addressing both genetic resources and traditional knowledge and for an 'international regime on access to genetic resources and benefit-sharing'. ${ }^{39}$ The outcome of these negotiations was the Nagoya Protocol that was finalised and adopted in $2010,{ }^{40}$ and entered into force on 12 October 2014. ${ }^{41}$

\footnotetext{
${ }^{30} \mathrm{CBD}$, Art 15(3).

${ }^{31} \mathrm{CBD}$, Art 15(5).

${ }^{32} \mathrm{CBD}$, Arts 15(4) and (7).

${ }^{33}$ See Charles Lawson, Regulating Genetic Resources: Access and Benefit-sharing in International Law (Edward Elgar, 2012) pp 130-154.

${ }^{34}$ Conference of the Parties to the Convention on Biological Diversity, Report of the Sixth Meeting of the Conference of the Parties to the Convention on Biological Diversity (2002) UNEP/CBD/COP/6/20, [342] and Annex 1 (Decision VI/24A, pp 253-269).

${ }^{35} \mathrm{UNEP} / \mathrm{CBD} / \mathrm{COP} / 6 / 20$, above $\mathrm{n} 34$, [340].

${ }^{36}$ See United Nations, Report of the World Summit on Sustainable Development (2002) A/CONF.199/20, [44(o)]. See also Conference of the Parties to the Convention on Biological Diversity, Report of the Ad Hoc Open-Ended Working Group on Access and Benefit-Sharing on the Work of its Second Meeting (2003) $\mathrm{UNEP} / \mathrm{CBD} / \mathrm{COP} / 7 / 6$.

${ }^{37}$ General Assembly of the United Nations, Resolution 57/260: Convention on Biological Diversity, $57^{\text {th }}$ Session (2003) A/RES/57/260, [7]-[9].

${ }^{38}$ See Conference of the Parties to the Convention on Biological Diversity, Report of the Seventh Meeting of the Conference of the Parties to the Convention on Biological Diversity (2004) UNEP/CBD/COP/7/21, [347] and Annex (Decision VII/19D, [1], p 300).

${ }^{39} \mathrm{UNEP} / \mathrm{CBD} / \mathrm{COP} / 7 / 21$, above n 38, [347] and Annex (Decision VII/19D, [1], p 300). For an overview of the negotiations see Lawson, above n 33, pp 137-151.

40 See UNEP/CBD/COP/10/27, above n 7, [103] and Annex (Decision X/1, Annex 1, pp 89-109).

${ }^{41}$ See Secretariat of the Convention on Biological Diversity, Governments Fulfill their Commitment: Access and Benefit-sharing Treaty Receives Required Number of Ratifications to Enter into Force, Press Release, 14 July 2014 at http://www.cbd.int/doc/press/2014/pr-2014-07-14-Nagoya-Protocol-en.pdf (viewed: 9 December 2014).
} 
The objective of the Nagoya Protocol is 'the fair and equitable sharing of the benefits arising from the utilization of genetic resources ${ }^{42}$ and applies to genetic resources covered by the CBD and the traditional knowledge associated with those genetic resources. ${ }^{43}$ The purpose of the protocol is to be 'the instrument for the implementation of the access and benefit-sharing provisions of the [CBD]'. ${ }^{44}$ Essentially the protocol imposes specific obligations on Members to support compliance through 'legislative, administrative and policy measures' with the CBD's access and benefit-sharing obligations through a contract based on prior informed consent and mutually agreed terms. ${ }^{45}$ The scope of the Nagoya Protocol is to the access and benefit-sharing obligations in the CBD as they relate to 'genetic resources' and 'traditional knowledge associated with genetic resources'. ${ }^{46}$ Special provision is made for sharing benefits with 'indigenous and local communities, in accordance with domestic legislation regarding the established rights of these indigenous and local communities over these genetic resources'. ${ }^{47}$ Then obligations are imposed on Members providing access to genetic resources to give a clear 'legislative, administrative and policy measures' to facilitate access, including clear rules and procedures, access permits, a clearing house mechanism, and so on. ${ }^{48}$ Special provision is made for accessing traditional knowledge associated with genetic resources requiring 'measures, as appropriate' for 'the prior and informed consent or approval and involvement of these indigenous and local communities, and that mutually agreed terms have been established'. ${ }^{49}$ In fulfilling these special provisions Members need to 'take into consideration indigenous and local communities' customary laws, community protocols and procedures, as applicable'. ${ }^{50}$ The protocol then sets out various machinery provisions: national focal points to make information available, ${ }^{51}$ competent national authorities to grant access permits (also called 'internationally recognise certificates of compliance’), ${ }^{52}$ clearing house to share information about legislative, administrative and policy measures, permits, model contract clause, and so on, ${ }^{53}$ ensuring compliance and dealing with non-compliance for

\footnotetext{
${ }^{42}$ Nagoya Protocol, Art 1.

${ }^{43}$ Nagoya Protocol, Art 3.

${ }^{44}$ Nagoya Protocol, Art 4(4).

${ }^{45}$ Nagoya Protocol, Arts 5(1) and (3).

${ }^{46}$ Nagoya Protocol, Art 3.

${ }^{47}$ Nagoya Protocol, Art 5(2).

${ }^{48}$ Nagoya Protocol, Arts 6(1) and (3).

${ }^{49}$ Nagoya Protocol, Art 7.

${ }^{50}$ Nagoya Protocol, Art 12(1).

${ }^{51}$ Nagoya Protocol, Art 13(1).

${ }^{52}$ Nagoya Protocol, Art 13(2).

${ }^{53}$ Nagoya Protocol, Art 14.
} 
genetic resources ${ }^{54}$ and traditional knowledge, ${ }^{55}$ and establishing checkpoints for monitoring prior informed consent and providing 'internationally recognise certificates of compliance’. ${ }^{56}$

The Nagoya Protocol addresses its relationship to other international agreements providing:

1. The provisions of this Protocol shall not affect the rights and obligations of any Party deriving from any existing international agreement, except where the exercise of those rights and obligations would cause a serious damage or threat to biological diversity. This paragraph is not intended to create a hierarchy between this Protocol and other international instruments.

2. Nothing in this Protocol shall prevent the Parties from developing and implementing other relevant international agreements, including other specialized access and benefit-sharing agreements, provided that they are supportive of and do not run counter to the objectives of the [CBD] and this Protocol.

3. This Protocol shall be implemented in a mutually supportive manner with other international instruments relevant to this Protocol. Due regard should be paid to useful and relevant ongoing work or practices under such international instruments and relevant international organizations, provided that they are supportive of and do not run counter to the objectives of the [CBD] and this Protocol.

4. This Protocol is the instrument for the implementation of the access and benefit-sharing provisions of the [CBD]. Where a specialized international access and benefit-sharing instrument applies that is consistent with, and does not run counter to the objectives of the [CBD] and this Protocol, this Protocol does not apply for the Party or Parties to the specialized instrument in respect of the specific genetic resource covered by and for the purpose of the specialized instrument. ${ }^{57}$

The Nagoya Protocol restates and extends the related relationship provision in the CBD that provided:

1. The provisions of this Convention shall not affect the rights and obligations of any Contracting Party deriving from any existing international agreement, except where the exercise of those rights and obligations would cause a serious damage or threat to biological diversity.

2. Contracting Parties shall implement this Convention with respect to the marine environment consistently with the rights and obligations of States under the law of the sea. ${ }^{58}$

The next step is to understand the interaction between UPOV 1991, the CBD and the Nagoya Protocol.

\footnotetext{
${ }^{54}$ Nagoya Protocol, Arts 15 and 17(1)(a)(ii).

${ }^{55}$ Nagoya Protocol, Art 16.

${ }^{56}$ Nagoya Protocol, Art 17(1).

${ }^{57}$ Nagoya Protocol, Art 4.

${ }^{58}$ CBD, Art 22.
} 


\section{The relationship between the CBD, the Nagoya Protocol and UPOV}

The Vienna Convention on the Law of Treaties (Vienna Convention) ${ }^{59}$ applies to international agreements between Nation States and governed by international law. ${ }^{60}$ The Vienna

Convention was adopted by the UN Conference on the Law of Treaties from a draft prepared by the International Law Commission (ILC). ${ }^{61}$ The ILC also prepared a commentary setting of the justification for the various articles. ${ }^{62}$ Importantly the Vienna Convention only codifies some of the customary law interpretation principles and many of these are 'discretionary rather than obligatory and the interpretation of documents is to some extent an art, and not an exact science'. ${ }^{63}$ Further, the interpretation principles 'are, for the most part, principles of logic and good sense valuable only as a guide to assist in appreciating the meaning which parties may have intended to attach to the expression that they employed in the document'. ${ }^{64}$ And then:

... suitability [of an interpretation principle] for use in any given case hinges on a variety of considerations which have first to be appreciated by the interpreter of the document; the particular arrangement of the words and sentences, their relation to each other and to other parts of the document, the general nature and subject-matter of the document, the circumstances in which it was drawn up, etc. Even when a possible occasion for their application may appear to exist, their application is not automatic but depends on the conviction of the interpreter that it is appropriate in the particular circumstances of the case. ${ }^{65}$

In effect this means that interpretation is fairly flexible taking advantage of many different factors and elements. As a generalisation, however, the majority view appears to be that, although there is no hierarchy of legal sources, interpretation tends to first focus on the text of the treaty and then taking into account various other extrinsic materials and the objects and purpose of the agreements. ${ }^{66}$ As such the Vienna Convention provides:

\footnotetext{
59 (1969) 1155 UNTS 331.

${ }^{60}$ Vienna Convention on the Law of Treaties, Arts 1 and 2(1)(a) ('Treaties'). 'Treaty' means 'an international agreement concluded between States in written form and governed by international law, whether embodied in a single instrument or in two or more related instruments and whatever its particular designation'.

${ }^{61}$ Mark Villiger, Commentary on the 1969 Vienna Convention on the Law of Treaties (Brill, 2009) pp 35-38.

${ }^{62}$ See International Law Commission, Yearbook of the International Law Commission, Volume II (1966)

A/CN.4/SER.A/1966/Add.1, pp 187-273.

${ }^{63}$ A/CN.4/SER.A/1966/Add.1, above n 62, p 218.

${ }^{64}$ A/CN.4/SER.A/1966/Add.1, above n 62, p 218.

${ }^{65}$ A/CN.4/SER.A/1966/Add.1, above n 62, p 218.

${ }^{66}$ A/CN.4/SER.A/1966/Add.1, above n 62, 218. See also United Nations General Assembly, International Law Commission: Report of the Work of its Fifty-seventh Session, $60^{\text {th }}$ Session Supplement No 10 (2005) A/60/10.
} 
1. A treaty shall be interpreted in good faith in accordance with the ordinary meaning to be given to the terms of the treaty in their context and in the light of its object and purpose.

2. The context for the purpose of the interpretation of a treaty shall comprise, in addition to the text, including its preamble and annexes:

(a) Any agreement relating to the treaty which was made between all the parties in connexion with the conclusion of the treaty;

(b) Any instrument which was made by one or more parties in connexion with the conclusion of the treaty and accepted by the other parties as an instrument related to the treaty.

3. There shall be taken into account, together with the context:

(a) Any subsequent agreement between the parties regarding the interpretation of the treaty or the application of its provisions;

(b) Any subsequent practice in the application of the treaty which establishes the agreement of the parties regarding its interpretation;

(c) Any relevant rules of international law applicable in the relations between the parties.

4. A special meaning shall be given to a term if it is established that the parties so intended. ${ }^{67}$

Where a meaning as interpreted is 'ambiguous or obscure', or 'manifestly absurd or unreasonable', then recourse may be had to 'supplementary means of interpretation, including the preparatory work of the treaty and the circumstances of its conclusion'. ${ }^{68}$ Importantly, where successive treaties deal with the same subject matter, ${ }^{69}$ then ' $[\mathrm{w}]$ hen a treaty specifies that it is subject to, or that it is not to be considered as incompatible with, an earlier or later treaty, the provisions of that other treaty prevail'. ${ }^{70}$ With this in mind the interaction between the CBD, Nagoya Protocol and UPOV can be assessed.

\section{The relationship between the CBD and the Nagoya Protocol}

The CBD makes provision for protocols adopted by the Conference of the Parties to the CBD $(\mathrm{COP})^{71}$ and their accession, ratification, acceptance or approval by States and by regional economic integration organizations to take effect. ${ }^{72}$ The COP may consider and adopt a protocol in carrying out its function to 'keep under review the implementation of this [CBD]' ${ }^{73}$ Only Contracting Parties to the CBD can become parties to a protocol and only parties to the protocol can make decisions under a protocol. ${ }^{74}$ Relying on these CBD

\footnotetext{
${ }^{67}$ Vienna Convention on the Law of Treaties, Art 31.

${ }^{68}$ Vienna Convention on the Law of Treaties, Art 32.

${ }^{69}$ Vienna Convention on the Law of Treaties, Art 30(1).

${ }^{70}$ Vienna Convention on the Law of Treaties, Art 30(2).

${ }^{71}$ CBD, Art 28.

${ }^{72}$ CBD, Arts 34-36.

${ }^{73}$ CBD, Art 23(4).

${ }^{74}$ CBD, Art 32.
} 
provisions the COP negotiated the Nagoya Protocol and it entered into force as a protocol to the CBD. ${ }^{75}$ The relationship between the CBD and Nagoya Protocol is then clearly stated the purpose of the protocol is to be 'the instrument for the implementation of the access and benefit-sharing provisions of the [CBD]' ${ }^{76}$ As an instrument for 'implementation' the preferable view is that the Nagoya Protocol reflects the Contracting Parties' understandings about the CBD and any interpretive issues would be assessed in the context of the CBD and its objectives. This is also consistent with the Vienna Convention provision that the CBD should prevail in dealing with any inconsistency as the Nagoya Protocol as a later treaty dealing with the same subject matter as the CBD and expressly compatible with the CBD. ${ }^{77}$

Significantly, both the CBD and Nagoya Protocol make express provision for other international agreements dealing with access and benefit-sharing the 'genetic resources' within the scope of the CBD and Nagoya Protocol. ${ }^{78}$ For plant breeding the most significant of these has been the International Treaty on Plant Genetic Resources for Food and Agriculture (Plant Treaty) ${ }^{79}$ that provides for a limited class of agricultural plants and establishes a specific access and benefit-sharing regime for these resources. ${ }^{80}$ This agreement was envisioned during the CBD negotiations ${ }^{81}$ because of the "special nature of agricultural biodiversity, its distinctive features and problems needing distinctive solutions, ${ }^{82}$ negotiated 'in harmony' with ${ }^{83}$ and the close oversight by the CBD’s COP, ${ }^{84}$ and the final Plant Treaty's

\footnotetext{
${ }^{75}$ See UNEP/CBD/COP/10/27, above n 7, [103] and Annex (Decision X/1).

${ }^{76}$ Nagoya Protocol, Art 4(4).

${ }^{77}$ Vienna Convention on the Law of Treaties, Arts 30(1) and (2).

${ }^{78}$ See CBD, Art 22, Nagoya Protocol, Art 4(2).

${ }^{79}$ International Treaty on Plant Genetic Resources for Food and Agriculture (2001) 2400 UNTS 303 (Plant Treaty). See also Food and Agriculture Organisation of the United Nations, Report of the Conference of FAO, Thirty-first Session (2001) C 2001/REP, [58] (Resolution 3/2001).

${ }^{80}$ See Lawson, above n 33, pp 181-217.

${ }^{81}$ See Conference of the Parties to the Convention on Biological Diversity, Medium-term Program of Work of the Conference of the Parties: Progress Report by the Food and Agriculture Organization of the United Nations (FAO) on work being carried out by the Commission on Plant Genetic Resources to implement Resolution 3 of the Nairobi Final Act (1993) UNEP/CBD/COP/1/INF/3, [1] and Annex 1.

${ }^{82}$ Conference of the Parties to the Convention on Biological Diversity, Report of the Second Meeting of the Conference of the Parties to the Convention on Biological Diversity (1995) UNEP/CBD/COP/2/19, [125] and Annex II (Decision II/15, p 68). See also Conference of the Parties to the Convention on Biological Diversity, Report of the Fifth Meeting of the Conference of the Parties to the Convention on Biological Diversity (1998) UNEP/CBD/COP/5/23, [131] and Annex III (Decision V/5, pp 100-101).

${ }^{83}$ Food and Agriculture Organisation of the United Nations, Report of the Conference of FAO, Twenty-Seventh Session (1993) C 1993/REP, [105] (Resolution 7/1993).

${ }^{84}$ See Conference of the Parties to the Convention on Biological Diversity, Report of the Fourth Extraordinary Session of the Commission on Genetic Resources for Food and Agriculture (1998) UNEP/CBD/COP/4/INF/20; Conference of the Parties to the Convention on Biological Diversity, Progress Under the FAO Global System for the Conservation and Sustainable Utilisation of Plant Genetic Resources for Food And Agriculture (1996) UNEP/CBD/COP/3/15/Add.1; Conference of the Parties to the Convention on Biological Diversity, FAO Global System for Plant Genetic Resources for Food and Agriculture (1995) UNEP/CBD/COP/2/18;
} 
objectives were expressed as 'the conservation and sustainable use of plant genetic resources for food and agriculture and the fair and equitable sharing of the benefits arising out of their use, in harmony with the [CBD], for sustainable agriculture and food security' and to 'be attained by closely linking' the Plant Treaty and the CBD. ${ }^{85}$ The Plant Treaty also recognises that it should be 'mutually supportive' of related sustainability international agreements, maintain existing rights and obligations under other international agreements, and not create a hierarchy of international agreements. ${ }^{86}$ And these links between the Plant Treaty and CBD have been formally recognised ${ }^{87}$ and maintained. ${ }^{88}$

The Nagoya Protocol, implementing the CBD, ${ }^{89}$ expressly recognises 'specialised international access and benefit-sharing instrument[s]' and provides that so long as they are 'consistent with, and do[] not run counter to the objectives' of the CBD and the Nagoya Protocol, then the Nagoya Protocol does not apply to those 'specific genetic resources'. ${ }^{90}$ This would appear to apply specifically to the Plant Treaty and this is consistent with the negotiating histories. ${ }^{91}$ Within this context, there seems little doubt that the Plant Treaty is a

Conference of the Parties to the Convention on Biological Diversity, FOA Global System for Plant Genetic Resources for Food and Agriculture (1995) UNEP/CBD/COP/2/INF/13/Rev.1; Conference of the Parties to the Convention on Biological Diversity, Medium-term Program of Work of the Conference of the Parties: Progress Report by the Food and Agriculture Organization of the United Nations (FAO) on work being carried out by the Commission on Plant Genetic Resources to implement Resolution 3 of the Nairobi Final Act (1993) $\mathrm{UNEP} / \mathrm{CBD} / \mathrm{COP} / 1 / \mathrm{INF} / 3$.

${ }^{85}$ Plant Treaty, Art 1. See also Arts 17(1), 19(3)(g), (l) and (m) and 20(5).

${ }^{86}$ Plant Treaty, Preamble.

${ }^{87}$ See UNEP/CBD/COP/6/20, above n 34, [107] and Annex I (Decision VI/6); Conference of the United Nations Food and Agriculture Organisation, Report of the Conference of FAO, Thirty-First Session (2001) C 2001/REP, [58] (Resolution 3/2001).

${ }^{88}$ See Conference of the Parties to the Convention on Biological Diversity, Report of the Eleventh Meeting of the Conference of the Parties to the Convention on Biological Diversity (2012) UNEP/CBD/COP/11/35, [159] and Annex 1 (Decision XI/6); UNEP/CBD/COP/10/27, above n 7, [246] and Annex (Decision X/20); Conference of the Parties to the Convention on Biological Diversity, Report of the Ninth Meeting of the Conference of the Parties to the Convention on Biological Diversity (2008) UNEP/CBD/COP/9/29, [371] and Annex 1 (Decision IX/27); Conference of the Parties to the Convention on Biological Diversity, Report of the Eighth Meeting of the Conference of the Parties to the Convention on Biological Diversity (2006) UNEP/CBD/COP/8/31, [329] and Annex 1 (Decision VIII/16); and so on.

${ }^{89}$ See Nagoya Protocol, Art 4(4).

${ }^{90}$ Nagoya Protocol, Art 4(4).

${ }^{91}$ See Commission on Genetic Resources for Food and Agriculture, Report of the Commission on Genetic Resources for Food and Agriculture (2001) CGRFA-Ex6/01/REP, [5]-[10]; Commission on Genetic Resources for Food and Agriculture, Report of the Fifth Extraordinary Session of the Commission on Genetic Resources for Food and Agriculture (1998) CGRFA-Ex5/98/REP, [7]-[42]; Commission on Genetic Resources for Food and Agriculture, Report of the Fourth Extraordinary Session of the Commission on Genetic Resources for Food and Agriculture (1997) CGRFA-EX4/97/REP, [5]-[14]; Commission on Genetic Resources for Food and Agriculture, Report of the Commission on Genetic Resources for Food and Agriculture (1996) CGRFAEx3/96/REP, [5]-[16]; Commission on Genetic Resources for Food and Agriculture, Report of the Commission on Genetic Resources for Food and Agriculture (1996) CGRFA-Ex2/96/REP, [32]-[39]; Commission on Plant Genetics Resources, Report of the Commission on Plant Genetics Resources (1994) CPGR-Ex1/94/REP, [11][15]. See also Thomas Greiber, Sonia Peña Moreno, Mattias Åhrén, Jimena Nieto Carrasco, Evanson Chege 
separate scheme that operates independently of both the CBD and the Nagoya Protocol and that the 'genetic resources' covered by the Plant Treaty are carved out from the CBD and Nagoya Protocol scheme - the Plant Treaty is a lex specialis to the CBD. ${ }^{92}$ This is also consistent with the Vienna Convention provision that the Plant Treaty as a later treaty dealing with the same subject matter as the CBD then the Plant Treaty prevails to the extent of the incompatibility. ${ }^{93}$

For plant breeder's rights the supremacy of the Plant Treaty is significant because the Plant Treaty deals expressly with plant breeder's rights as a form of intellectual property. ${ }^{94}$ These provisions enable materials to be made available subject to a plant breeder's right ${ }^{95}$ and plant breeder's rights to be claim except over the materials 'in the form received' under the Treaty. ${ }^{96}$ For materials made available under the Plant Treaty a Standard Materials Transfer Agreement (SMTA) imposes obligations on providers and recipients. ${ }^{97}$ The recipients are obliged by the SMTA to maintain the Plant Treaty obligations in future dealings with the materials so that materials once accessed under an SMTA start a lineage of SMTAs and their obligations attached to the evolving materials. ${ }^{98}$ Most importantly, where plant breeder's rights are claimed there will be a breeder’s exemption consistent with UPOV 1991. The breeder's exemption will, however, be subject to the terms and conditions imposed by the Plant Treaty’s SMTA. The SMTA does not presently attempt to limit the UPOV breeder's exemption ${ }^{99}$ meaning that plants accessed under the Plant Treaty that are plant breeder's right protected can be used to breed new varieties.

\footnotetext{
Kamau, Jorge Cabrera Medaglia, Maria Julia Oliva and Frederic Perron-Welch in cooperation with Natasha Ali and China Williams, An Explanatory Guide to the Nagoya Protocol on Access and Benefit-sharing, IUCN Environmental Policy and Law Paper No 83 (IUCN, 2012) p 35.

92 See also Ad Hoc Open-ended Working Group on Access and Benefit-Sharing, Study on the Relationship between an International Regime on Access and Benefit-Sharing and other International Instruments and Forums that Govern the Use of Genetic Resources (2009) UNEP/CBD/WG-ABS/7/INF/3/Part.1, [4] and Annex ([3.3.19]).

${ }^{93}$ Vienna Convention on the Law of Treaties, Arts 30(1) and (3).

${ }^{94}$ Plant Treaty, Arts 12(3)(d) and (f). See also Lawson, above n 25.

${ }^{95}$ Plant Treaty, Art 12(3)(f).

${ }^{96}$ Plant Treaty, Art 12(3)(d).

${ }^{97}$ Plant Treaty, Art 12(4); Food and Agriculture Organization of the United Nations, First Session of the Governing Body of the International Treaty on Plant Genetic Resources for Food and Agriculture (2006) IT/GB-1/06/Report, [12] (Resolution 2/2006) and Appendix G.

${ }^{98}$ Food and Agriculture Organization of the United Nations, First Session of the Governing Body of the International Treaty on Plant Genetic Resources for Food and Agriculture (2006) IT/GB-1/06/Report, [12] and Appendix G (Art 6.4).

${ }^{99}$ Food and Agriculture Organization of the United Nations, First Session of the Governing Body of the International Treaty on Plant Genetic Resources for Food and Agriculture (2006) IT/GB-1/06/Report, [12] and Appendix G.
} 


\section{The relationship between the UPOV and the CBD/Nagoya Protocol}

The next interpretation task is to assess the relevant provisions of the CBD as a later agreement possibly affecting the applications of UPOV 1991 as an earlier agreement. Here the Vienna Convention has relevance: where treaties deal with the same 'subject matter' then the later treaty takes precedence over incompatible provisions in the earlier treaty ${ }^{100}$ unless the later treaty specifies otherwise. ${ }^{101}$ There are two issues here: the 'subject matter' question and the declared compatibility question. ${ }^{102}$

A treaty will deal with the same 'subject matter' if they are incompatible in the sense that the provision of each treaty cannot be complied with simultaneously. ${ }^{103}$ Through interpretation this might be relaxed so that an interpretation that allows treaties to be compatible should be favoured. ${ }^{104}$ In the present context the CBD (and Nagoya Protocol) deals with access and benefit-sharing genetic resources and the UPOV 1991 deals with plant breeder's rights. These are different subject matters because the UPOV 1991 does not deal with access and benefit sharing genetic resources. ${ }^{105}$ In response to a CBD Secretariat request, ${ }^{106}$ the Council of UPOV responded:

UPOV considers that plant breeding is a fundamental aspect of the sustainable use and development of genetic resources. It is of the opinion that access to genetic resources is a key requirement for sustainable and substantial progress in plant breeding. The concept of the 'breeder’s exemption' in the [UPOV 1991],

\footnotetext{
${ }^{100}$ Vienna Convention on the Law of Treaties, Art 30(3).

${ }^{101}$ Vienna Convention on the Law of Treaties, Art 30(2).

${ }^{102}$ For other analyses: see Thomas Greiber, Sonia Peña Moreno, Mattias Åhrén, Jimena Nieto Carrasco, Evanson Chege Kamau, Jorge Cabrera Medaglia, Maria Julia Oliva and Frederic Perron-Welch in cooperation with Natasha Ali and China Williams, An Explanatory Guide to the Nagoya Protocol on Access and Benefitsharing, IUCN Environmental Policy and Law Paper No 83 (IUCN, 2012) pp 75-81; Lyle Glowka, Françoise Burhenne-Guilmin and Hugh Synge in collaboration with Jeffrey McNeely and Lothar Gündling, A Guide to the Convention on Biological Diversity, IUCN Environmental Policy and Law Paper No 30 (IUCN, 1994) pp 109110.

${ }^{103}$ See Oliver Dörr and Kirsten Schmalenbachpp, Vienna Convention on the Law of Treaties: A Commentary (Springer, 2012) pp 510-511.

${ }^{104}$ See Oliver Dörr and Kirsten Schmalenbachpp, Vienna Convention on the Law of Treaties: A Commentary (Springer, 2012) p 511.

${ }^{105}$ See Ad Hoc Open-ended Working Group on Access and Benefit-Sharing, Compilation of Submissions Provided by Parties, Governments, International Organizations, Indigenous and Local Communities and Relevant Stakeholders Related to the International Regime on Access and Benefit-sharing (2006) UNEP/CBD/WG-ABS/4/INF/3, p 50. See also Ad Hoc Open-ended Working Group on Access and BenefitSharing, Study on the Relationship between an International Regime on Access and Benefit-sharing and other International Instruments and Forums that Govern the Use of Genetic Resources (2009) UNEP/CBD/WGABS/7/INF/3/Part.2, [50]; International Union for the Protection of New Plant Varieties, Access to Genetic Resources and Benefit-sharing - Reply of UPOV to the Notification of June 26, 2003, from the Executive Secretary of the Convention on Biological Diversity (CBD) (2003) C/37/20, Annex II.

${ }^{106}$ See C/37/20, above n 105, Annex 1. See also UNEP/CBD/COP/6/20, above n 34, [342] and Annex 1 (Decision VI/24A, [9]).
} 
whereby acts done for the purpose of breeding other varieties are not subject to any restriction, reflects the view of UPOV that the worldwide community of breeders needs access to all forms of breeding material to sustain greatest progress in plant breeding and, thereby, to maximize the use of genetic resources for the benefit of society. In addition, the [UPOV 1991] has inherent benefit-sharing principles in the form of the breeder's exemption and other exceptions to the breeder's right and UPOV is concerned about any other measures for benefit-sharing which could introduce unnecessary barriers to progress in breeding and the utilization of genetic resources. $^{107}$

The UPOV concern was not about an incompatibility because UPOV 1991 'is not an instrument relating to access and benefit-sharing', ${ }^{108}$ but rather that the COP not adopt an access and benefit-sharing regime that undermined UPOV. ${ }^{109}$ The UPOV Council requested ${ }^{110}$ and subsequently the Nagoya Protocol acknowledged the mutually supporting position of UPOV 1991: 'Recognising that international instruments related to access and benefit-sharing should be mutually supportive with a view to achieving the objectives of the [CBD]'. ${ }^{111}$ In short, the CBD (and Nagoya Protocol) and the UPOV 1991 do not appear to have 'subject matter' that is considered to be incompatible.

The next issue is whether the CBD (and Nagoya Protocol) and the UPOV 1991 are declared to be compatible? The CBD and Nagoya Protocol expressly provide that they do not affect the rights and obligations of any existing international agreement, such as UPOV 1991, 'except where the exercise of those rights and obligations would cause a serious damage or threat to biological diversity'. This was a compromise text adopted during negotiations to allay the concerns of some parties that the CBD might be relied on to limit prior agreements,

\footnotetext{
${ }^{107}$ C/37/20, above n 105, Annex II([17]). See also UNEP/CBD/WG-ABS/7/INF/3/Part.2, above n 105, [50]; Ad Hoc Open-ended Working Group on Access and Benefit-Sharing, Analysis of Existing National, Regional and International Legal Instruments Relating to Access and Benefit-sharing and Experience Gained in their Implementation, Including Identification of Gaps (2004) UNEP/CBD/WG-ABS/3/2, [25]-[26]; Ad Hoc Openended Working Group on Access and Benefit-Sharing, Compilation of submissions provided by parties, governments, international organizations, indigenous and local communities and relevant stakeholders in preparation for the third meeting of the ad hoc open-ended working group on access and benefit-sharing (2003) UNEP/CBD/WG-ABS/3/INF/1, p 107.

${ }^{108} \mathrm{UNEP} / \mathrm{CBD} / \mathrm{WG}-\mathrm{ABS} / 7 / \mathrm{INF} / 3 / \mathrm{Part} .2$, above $\mathrm{n}$ 105, [48].

${ }^{109}$ See UNEP/CBD/WG-ABS/7/INF/3/Part.2, above n 105, [48]. See also C/37/20, above n 105, Annex II([17]); Ad Hoc Open-ended Working Group on Access and Benefit-Sharing, Compilation of Submissions Provided by Parties, Governments, International Organizations, Indigenous and Local Communities and Relevant Stakeholders Related to the International Regime on Access and Benefit-sharing (2006) UNEP/CBD/WGABS/4/INF/3, p 51.

${ }^{110}$ See International Union for the Protection of New Varieties of Plants, Report (2008) C(Extr.)/25/10, [25][26]. See also Ad Hoc Open-ended Working Group on Access and Benefit-Sharing, Overview of Recent Developments at the International Level Relating to Access and Benefit-sharing (2007) UNEP/CBD/WGABS/5/4/Add.1, [45]; UNEP/CBD/WG-ABS/7/INF/3/Part.2, above n 105, [51].

${ }^{111}$ Nagoya Protocol, Preamble.
} 
including intellectual property agreements. ${ }^{112}$ Can UPOV 1991 damage and threaten biological diversity? This does not seem likely.

The purpose of UPOV 1991 was 'to ensure that the members of the Union acknowledge the achievement of breeders of new varieties of plants, by granting to them an intellectual property right, on the basis of a set of clearly defined principles'. ${ }^{113}$ This is achieved by providing a period of exclusivity for certain dealings with plant breeder's right protected varieties. Importantly, only plant varieties that satisfy the thresholds gain protection (essentially being new, distinct, uniform and stable), ${ }^{114}$ these exclusive rights are limited (being production or reproduction, conditioning for the purpose of propagation, offering for sale, selling or other marketing, exporting, importing, and stocking for any of the purposes, of propagating materials, harvested materials and essentially derived varieties), ${ }^{115}$ and the acts for private and non-commercial purposes, experimental purposes and breeding are expressly allowed. ${ }^{116}$ With these limitation in place it seem unlikely that the scope of the exclusive rights provided by UPOV 1991 could be said to damage and threaten biological diversity. This suggests that the CBD's and Nagoya Protocol's express provision that they do not affect the rights and obligations of any existing international agreement, and means that the CBD and Nagoya Protocol and the UPOV 1991 are likely compatible. ${ }^{117}$ And also this seems to be confirmed by the Nagoya Protocol expressly providing that there is not intended to be 'a hierarchy between this [Nagoya Protocol] and other international instruments’. ${ }^{118}$

It should be remembered, however, that the relationship between intellectual property and the CBD's access and benefit-sharing scheme has been long and contested. ${ }^{119}$ The main sites of contest have been over defensive protection to prevent the grant of intellectual property where there is misappropriation of the genetic resources (terms 'biopiracy'), disclosure

\footnotetext{
112 See Melinda Chandler, 'The Biodiversity Convention: Selected Issues of Interest to the International Lawyer' (1993) 4 Colorado Journal of International Environmental Law and Policy 141, 148-150.

${ }^{113}$ UPOV Publication No 437(e), above n 1, p 1.

${ }^{114}$ UPOV, Art 5(1).

${ }^{115}$ UPOV, Art 14.

${ }^{116}$ UPOV, Art 15.

${ }^{117}$ Notably this is consistent with the predominating view at the time of the CBD's negotiation: see Chandler, above n 112, 148-150.

118 Nagoya Protocol, Art 4(1).

${ }^{119}$ For an overview of these developments see Malbon et al., above n 13, pp 391-400.
} 
requirements in patent applications and the form and content of mutually agreed terms. ${ }^{120}$ This reflects the initial concern in the CBD that:

recognizing that patents and other intellectual property rights may have an influence on the implementation of this Convention, shall cooperate in this regard subject to national legislation and international law in order to ensure that such rights are supportive of and do not run counter to its objectives. ${ }^{121}$

The Nagoya Protocol then provides:

each Party requiring prior informed consent shall take the necessary legislative, administrative or policy measures, as appropriate, to: ... (g) Establish clear rules and procedures for requiring and establishing mutually agreed terms. Such terms shall be set out in writing and may include, inter alia: ... (ii) Terms on benefit-sharing, including in relation to intellectual property rights. ${ }^{122}$

The analysis so far suggests that the CBD and Nagoya Protocol can co-exist with the UPOV 1991. The problem remains, however, that both the CBD and Nagoya Protocol impose obligations on genetic resources and traditional knowledge associated with those genetic resources. How can those obligations be reconciled with the exclusivity and exemptions enabled by UPOV 1991? This is best addressed by understanding that a plant breeder's right, like other intellectual property, is a negative right that prevents others from using the protected plant variety. The plant breeder's right does not positively allow the owner of the protected plant variety to deal with it, and other regulatory schemes can limit those dealing, such as health and safety schemes, sanitary and phytosanitary laws, market access schemes, and so on. Considered this way the UPOV 1991 plant breeder's right can be granted over genetic resources addressed by the CBD and Nagoya Protocol, but the dealings with the protected variety can be subject to other obligations imposed according to the CBD and Nagoya Protocol schemes. This points to the next issue - State obligations and private actors exercised through contracts.

\section{State obligations and private actors}

At its most simple the Nagoya Protocol in detailing the CBD's access and benefit-sharing obligations distinguished between providers of genetic resources and their associated

\footnotetext{
${ }^{120}$ See Lawson, above n 33, pp 146-149.

${ }^{121}$ CBD, Art 16(5).

${ }^{122}$ Nagoya Protocol, Art 6(3).
} 
traditional knowledge and users of genetic resources and their associated traditional knowledge. The providers give access to the genetic resources and their associated traditional knowledge. ${ }^{123}$ And in exchange the users agree to deliver benefits. ${ }^{124}$ The State's obligations are to implement the necessary 'legislative, administrative and policy measures' so that providers and users can reach agreements according to the required prior informed consent and mutually agreed terms. ${ }^{125}$ Meanwhile it is the private actors that deal with the 'genetic resources' covered by Nagoya Protocol seeking prior informed consent and settling the mutually agreed terms. ${ }^{126}$ It is also the private actors that deal with the intellectual property claims including plant breeder's rights under UPOV 1991. While the analysis in this article shows that in interpreting UPOV 1991, and the CBD and Nagoya Protocol, there is not direct overlap in subject matters and there is no obvious incompatibility, and the analysis the UPOV 1991 breeder's exemption would appear to have a clear operation unencumbered by either the CBD or the Nagoya Protocol, this is perhaps an over simplification. Clearly, the terms and conditions imposed by the agreement between the providers and users in satisfying prior informed consent and reaching mutually agreed terms can limit the UPOV 1991 breeder's exemption. And this is the important point, it is the private actors within the State's 'legislative, administrative and policy measures' for prior informed consent and mutually agreed terms that actually finally agree on the scope, content and operation of intellectual property, including the limits of the UPOV 1991 breeder's exemption.

The long held disputes about access and benefit-sharing and intellectual property ${ }^{127}$ are a part of the larger problem that the CBD’s Contracting Parties have been slow to implement access and benefit-sharing schemes (the 'legislative, administrative and policy measures'). This is particularly the case for obligations on users, and this was the driving imperative for starting the negotiation of the Nagoya Protocol. ${ }^{128}$ The outcome of the Nagoya Protocol has been to more clearly articulate these obligations including the requirement for State’s to set out 'clear

\footnotetext{
${ }^{123}$ Nagoya Protocol, Arts 5(1), (2) and (5).

${ }^{124}$ Nagoya Protocol, Arts 5(1), (2) and (5).

125 Nagoya Protocol, Art 5(1) and (5), 6(1) and 7(1).

${ }^{126}$ See Matthias Buck and Clare Hamilton, 'The Nagoya Protocol on Access to Genetic Resources and the Fair and Equitable Sharing of Benefits Arising from their Utilization to the Convention on Biological Diversity' (2011) 20(1) Review of European Community and International Environmental Law 47-61, 48. ${ }^{127}$ These debates have essentially crystallized into discussions about disclosure of origin, source of legal provenance, protecting traditional knowledge, trademarks and the like, and so on: see United Nations Conference on Trade and Development, The Convention on Biological Diversity and the Nagoya Protocol: Intellectual Property Implications - A Handbook on the Interface between Global Access and Benefit Sharing Rules and Intellectual Property (UNCTAD, 2014).

${ }^{128}$ See A/Conf.199/20, above n 36, [44(o)].
} 
rules and procedures for requiring and establishing mutually agreed terms', including addressing intellectual property. ${ }^{129}$ To reach this agreement, however, contentious intellectual property issues were left out so that the Nagoya Protocol (and CBD) does not provide a detailed understanding of how intellectual property should be negotiated in settling mutually agreed terms. ${ }^{130}$ The result is that States are left to either implement 'legislative, administrative and policy measures' or leave the private actor providers and users to settle mutually agreed terms. This raises two immediate questions: first, what have States done to implement 'legislative, administrative and policy measures' for prior informed consent and mutually agreed terms about plant breeder's rights and exemptions?; and secondly, are there any restrictions in other laws that can contractually limit exclusions and exemptions of a plant breeder's right under UPOV 1991? Addressing each of these questions in turn using Australia as a case study.

States that have implemented access and benefit-sharing 'legislative, administrative and policy measures' to various degrees, and none of these dictate the form or content of the plant breeder's rights and exemptions that must, or must not, be adopted in reaching mutually agreed terms. ${ }^{131}$ In effect, it is left to the providers and users to decide the form or content of the plant breeder's rights and exemptions that they will impose on the accessed genetic resources. In Australia the access and benefit-sharing laws are essentially either regulated for some pubic lands, ${ }^{132}$ or left unregulated for private lands. The unregulated private lands leave the negotiation of access and benefit sharing entirely in the hands of the parties with no obligations to share any benefits and no limits on contracts limiting breeder's exemptions. The regulated access and benefit sharing provides for a benefit-sharing agreement, ${ }^{133}$ and sets some of the details that must be included in such an agreement. ${ }^{134}$ Significantly, the requirements for benefit sharing are only an obligation to disclose what benefits are shared

\footnotetext{
${ }^{129}$ Nagoya Protocol, Art 6(3)(iii).

${ }^{130}$ See UNCTAD Handbook, above n 127, p 12.

${ }^{131}$ See Secretariat to the Convention on Biological Diversity, Database on ABS Measures (CBD, 2014) available at http://www.cbd.int/abs/measures/ (viewed: 9 December 2014).

${ }^{132}$ Environment Protection and Biodiversity Conservation Act 1999 (Cth) s 301; Environment Protection and Biodiversity Conservation Regulations 2000 (Cth) rr 8A.01-8A.20; Biological Resources Act 2006 (NT); Biodiscovery Act 2004 (Qld).

${ }^{133}$ Environment Protection and Biodiversity Conservation Regulations 2000 (Cth) r 8A.07(1); Biological Resources Act 2006 (NT) s 27(1); Biodiscovery Act 2004 (Qld) s 33(1).

${ }^{134}$ Environment Protection and Biodiversity Conservation Regulations 2000 (Cth) r 8A.08; Biological Resources Act 2006 (NT) s 27(2); Biodiscovery Act 2004 (Qld) s 34(2).
} 
with no details about the form, content or quantum of benefits. ${ }^{135}$ Further, like the unregulated private lands, there is no limit on contracting out of the breeder's exemption. In short, settling the mutually agreed terms requirements for the purposes of the CBD and Nagoya Protocol allows for the contracting out of the UPOV 1991 breeder's exemption.

\section{Conclusions}

The analysis in the article shows that the UPOV 1991 and the CBD and Nagoya Protocol are compatible. This, however, overlooks the operational effect of the UPOV 1991, CBD and Nagoya Protocol in domestic laws and the ability to contract out of the UPOV 1991 breeder's exemption. In short, the UPOV 1991 and the CBD and Nagoya Protocol are compatible, albeit the contracts contemplated under the CBD and Nagoya Protocol allow the effect of the UPOV 1991 breeder's exemption to be negated. And this is consistent with the same outcomes under the Plant Treaty and it's SMTA, albeit the SMTA does not presently limit the UPOV breeder's exemption.

\footnotetext{
${ }^{135}$ See Environment Protection and Biodiversity Conservation Regulations 2000 (Cth) rr 8A.08(g), (i), (k) and (l); Biological Resources Act 2006 (NT) s 27(2); Biodiscovery Act 2004 (Qld) s 34(2)(c).
} 